\title{
Manajemen Bimbingan Dan Konseling Dalam Pendidikan Karakter Peserta Didik
}

\author{
Wahyu Hidayat ${ }^{1}$, Yaya Suryana ${ }^{2}$, Fia Fauziah ${ }^{3}$ \\ Universitas Islam Negeri Sunan Gunung Djati Bandung \\ wahyuhidayat@uinsgd.ac.id ${ }^{1}$, yayasuryana@uinsgd.ac.id ${ }^{2}$, \\ fiafauziah40@gmail.com ${ }^{3}$
}

\begin{abstract}
Abstrak
Kegiatan Bimbingan dan Konseling memegang peranan yang sangat penting dalam menumbuhkembangkan karakter siswa madrasah. Oleh karena itu, kegiatan bimbingan dan konseling harus ditata dan kelola secara sistematis dengan mengimplementasikan fungsi-fungsi manajemen, Penelitian ini bertujuan untuk mengetahui (1) perencanaan, (2) pengorganisasian (3) pelaksanaan (4) evaluasi (5) faktor penunjang dan penghambat (6) Hasil yang dicapai dari manajemen bimbingan dan konseling dalam pendidikan karakter peserta didik. Metode penelitian yang digunakan bersifat deskriptif-kualitatif, teknik pengumpulan data dilakukan melalui wawancara, observasi dan studi dokumentasi atau menyalin. Hasil penelitian ini menunjukan bahwa Manajemen bimbingan dan konseling dalam pendidikan karakter peserta didik telah berjalan cukup baik yang ditunjukan dengan beberapa hal berikut, yaitu: (1) perencanaanya secara adminstrasi sudah cukup baik. (2) pegorganisasiannya dilakukan sistem koordinasi baik antara guru bimbingan dan konseling dengan guru-guru mata pelajaran ataupun wali kelas. (3) pelaksanaanya disesuaikan dengan program-program yang telah di rumuskan sebelumnya.(4) evaluasi dilakukan dalam bentuk laporan.(5) faktor penunjangnya yaitu pemahaman Bimbingan Konseling seluruh civitas akademika baik, Sementara faktor penghambatnya kurangnya sumber daya manusia menyebabkan kurang optimalnya dalam pelaksanaan bimbingan dan konseling (6) hasil yang dicapai dilihat dari perubahan tingkah laku serta prestasi peserta didik.
\end{abstract}

Kata Kunci: Bimbingan, Konseling, Karakter

\section{Pendahuluan}

Pendidikan merupakan suatu unsur pentingdalam pengembangan kualitas seseorang. Dengan adanya hal itu setiap individu dapat berkembang baik dalam wawasan keilmuan, maupun potensi yang dimiliki. Dalam Kamus Besar Indonesia pendidikan ialah suatu cara untuk mematangkan individu dengan adanya usaha pengajaran dan pelatihan dalam proses perubahan tingkah laku individu atau kelompok (Syah, 2017: 210). 
Kurangnya potensi atau kemampuan individu terutama dalam kematangan psikososiospiritual disebabkan oleh pendidikan yang mengabaikan adanya bimbingan dan hanya berfokus pada administrasi serta pengajaran yang diberikan, seorang individu hanya akan cerdas dan terampil secara akademik saja dan kurang secara psikososiospiitual (Yusuf, 2005:53).

Bimbingan merupakan suatu bantuan berupa arahan dalam membantu seseorang baik secara individu maupun kelompok, baik yang bersifat peventif atau refresif dalam menangani kesulitan yang sedang dialami agar tercapai kesejahteraan dalam hidupnya (Walgito, 2010:7).

Konseling adalah suatu proses interaksi dimana satu orang dan lainnya (konselor dan klien) berusaha untuk memmahmi dan menemukan masalahnya. Dalam hal ini konseling memiliki pengertian bahwa adanya interaksi baik antara konselor dengan klien, dimana konselor berusaha untuk membantu menemukan serta memahami masalah yang sedang dihadapi oleh kliennya masalahnya (Hikmawati, 2012:22).

Sadewo dalam Gunawan (2012:2) mengungkapkan karakter merupakan sekumpulan tingkah laku dari seorang manusia yang didalamnya terdapat perwujudan dari kesadaran dalam melaksanakan peran, fungsi, dan tugas dalam mengemban amanah dan tanggung jawab.

Bimbingan dan konseling di Madrasah Aliyah Negeri 1 Kota Bandung dilaksanakan ketika ada jam kosong di kelas, kecuali untuk kelas 12 adanya waktu khusus 1 jam dalam seminggu tentang bimbingan karier untuk mempersiapkan peserta didiknya yang ingin melanjutkan studi ke jenjang perguruan tinggi.Madrasah Aliyah Negeri 1 Kota Bandung memiliki guru bimbingan konseling sejumlah 3 orang dan yang tentunya harus mampu melayani para peserta didiknya yang ingin berkonsultasi, dalam hal ini seharusnya guru bimbingan dan konseling memiliki rasio 1: 150 siswa namun dalam kenyataannya guru BK yang berada disana memiliki jumlah yang sedikit untuk jumlah siswa yang tergolong banyak. Adapun yang berkaitan dengan pendidikan karakter yang berada di Madrasah Aliyah Negeri 1 Kota Bandung yaitu menerapkan nilai-nilai karakter seperti rasa hormat kepada para guru baik kepada guru yang mengajar peserta didik tersebut maupun guru yang tidak mengajar kepada peserta didik tersebut. Dalam hal ini tentunya berkaitan tentang bagaimana seorang peserta didik tetap menghormati gurunya dan memberikan salam maupun sapa terhadap semua guru baik kepada guru yang pernah mengajar maupun tidak mengajar, adapun penerapan karakter lainnya yang diterapkan yaitu pada nilai taqwa dan religius yaitu bagaimana madrasah mewajibkan peserta didinya melakukan sholat berjama'ah di waktu dzuhur dan mendengarkan kultum sebelum shalat dzuhur. Adapun pembeda antara penelitian yang relevan dengan judul yang diteliti yaitu berfokus pada manajemen bimbingan dan konseling dalam pendidikan karakter siswa yang didalamnya menyangkut bagaimana bimbingan dan konseling dalam mengatur atau mengarahkan para peserta didik dalam menerapkan nilai-nilai pendidikan karakter disekolah atau madrasah. 


\section{Metode}

Metode penelitian yang digunakan bersifat deskriptif-kualitatif, teknik pengumpulan data dilakukan melalui wawancara, observasi dan studi dokumentasi atau menyalin. Menurut Moleong (2012:6) Penelitian kualitatif bermaksud untuk memahami fenomena tentang apa yang telah dialami oleh subjek penelitian misalnya prilaku persepsi, motivasi tindakan dan lain sebagainya secara holistik, serta dengan cara deskripsi dalam bentuk bahasa dan kata-kata yang diuraikan pada konteks khusus yang alamiah dengan memanfaatkan metode alamiah. Adapun tehnik pengumpulan data diperoleh dari wawancara, observasi, dan studi dokumentasi.

\section{Hasil Dan Pembahasan}

Manajemen bimbingan dan konseling yang dilaksanakan di Madrasah Aliyah Negeri 1 Kota Bandung pada dasarnya dilakukan sesuai dengan arahan kepala Madrasah dan tujuan yang telah ditetapkan.Tujuan utama dari bimbingan dan konseling itu sendiri yaitu fokus terhadap perkembangan peserta didik.dalam pelaksanaannya secara teknis BK menghubungi guru/wali kelas atau BK terjun langsung menemui peserta didik maupun sebaliknya hal ini dikarenakan bahwa BK tidak masuk pada program kurikulum yang sedang berlaku. Sedangkan untuk evaluasi bimbingan dan konseling dilakukan bersama dengan kepala madrasah.

Adapun nilai-nilai karakter yang diterapkan yaitu dalam kedisiplinan, religius, ketaqwaan, rasa hormat, sosialisasi hal ini dibuktikan dengan adanya berbagai kegiatan yang dilaksanakan seperti sholat dzuhur berjamaah, dan kegiatan khusus karakter seperti camping yang diadakan khusus untuk melatih rasa percaya diri, kedisiplinan, serta melatih mental peserta didik dan ekstrakurikuler yang menunjang pada pembentukan kararkter peserta didik.

Pada Perencanaan bimbingan dan konseling di Madrasah Aliyah Negeri 1Kota Bandung langkah awal yang dilakukan adalah analisis kebutuhan peserta didik hal ini dilakukan dengan alat-alat bimbingan konseling seperti ITP, DCM (Daftar Cek Masalah) Dalam rumusan tujuan yang dilaksanakan di Madrasah Aliyah Negeri 1 Kota Bandung yaitu berpacu pada perkembangan peserta didik, sederhananya peserta didik pada usia SMA/ MA sedang dalam tahap perkembangan. Pada Tujuan dan landasan layanan bimbingan konseling di Madrasah Aliyah Negeri 1 Kota Bandung yaitu berpacu pada perkembangan peserta didik, sederhananya peserta didik pada usia SMA/ MA sedang dalam tahap perkembangan. oleh karena itu, pihak BK di madrasah harus fokus pada perkembangan peserta didik, karena dalam masa perkembangannya peserta didik bukan hanya membutuhkan ilmu-ilmu keterampilan akademik saja melainkan dibantu dengan adanya bimbingan sesuai tahapan pekembangan peserta didik. pada dasarnya peserta didik pada usia remaja membutuhkan sebelas poin kebutuhan dari sebelas poin tersebut disitulah pihak BK berkecimpung didalamnya, sehingga peserta didik yang lulus dari Madrasah Aliyah Negeri 1 Kota Bandung mampu berkembang menjadi pribadi yang paripurnanya artinya bertambah dari segi ilmu pengetahuan, sosial maupun kepribadiannya. Maka peran BK sangat penting karena dalam dunia pendidikan unsur terpenting dari 
seorang peserta didik yaitu Administrasi, kurikulum/akademik dan BKSedangkan pada penetapan jenis kegiatan konselor perlu memisahkan setiap tujuan dan jenis kegiatan yang tepat untuk stiap tujuan yang ingin dicapainya

Adapun penentuan waktu dan tempat kegiatan bimbingan dan konseling di Madrasah Aliyah Negeri 1 Kota Bandung perlu diperhatikan karena tidak dapat dipisahkan dari penentuan jenis, teknis dan strategi bimbingan dan konseling kedua kegiatan ini tidak dapat dipisahkan karena menjadi acuan dalam pelaksanaan bimbingan dan konseling. Selain itu penentuan Fasilitas merupakan fasilitas baik secara fisik maupun teknis, fasilitas ini merupakan faktor yang sangat menentukan dalam pelaksanaan program bimbingan dan konseling di sekolah/ madrasah. Falisitas tersebut meliputi, ruang Bk yang didalamnya terdapat ruang kerja konselor, ruang tunggu, ruang pertemuan dan alat-alat perlengkapan beserta alat-alat penghimpun data seperti angket dan lainnya.

Dalam pengorganisasan bimbingan dan konseling di Madrasah Aliyah Negeri 1 Kota Bandung langsung dari arahan kepala Madrasah dibantu dengan wali kelas dan guru-guru mata pelajaran tetapi sifatnya bukan perintah melainkan bersifat koordinasi dalam pelaksanaan kegiatan bimbingan dan koseling.Adapun tugas dan wewenang dari masing-masing SDM BK di Madrasah Aliyah Negeri 1 Kota Bandung diantaranya:. !) Kepala Sekolah memiliki tugas dan fungsi yangterbagi menjadi beberapa kegiatan baik kegiatan harian, mingguan, bulanan kegiatan akhir semester serta tahun pelajaran, kaitannya dengan kegiatan BK tugas kepala madrasah melakukan supervisi mingguan, selain itu mengevaluasi seluruh program kegiatan baik secara harian, mingguan, atau bulanan. 2) Koordinator BK/BP mempunyai tugas dan fungsi yaitu merencanakan dan mebuat kegiatan dalam bentuk program BK,membuat perencanaan kegiatan BK, adanya koordinasi dengan guru BK, menyusun dan melaksnakan program, adminstrasi, menilai, adanya tindak lanjut, adanya usulan kepada kepa sekolah atau madrasah terutama dalam sarana dan prasana BK, mempertanggung jawabkan kegiatan BK, adanya test unrtuk mengetahui minat dan bakat peserta didik serta membuat laporan . 3) Guru pembimbing BK memiliki tugas-tugas diantaranya sebagai berikut Mensosialisasikan kegiatan BK, membuat perencanaan BK, melaksanakan dan mepersiapkan kegiatan BK baik dari berbagai jenis layanan yang ada, mengevaluasi, maenganalisis, adminstrasi kegiatan $\mathrm{BK}$, menganalisis hasil penilaian $\mathrm{BK}$, kunjungan rumah serta adanya arahan yang diberikan kepada siswa dalam menjalankan tata tertib yang ada dilingkungan madrasah atau sekolah. 4) Wali kelas berperan sebagai orang tua siswa ketika disekolah, mengawasi kegiatan siswa dikelas, memberi arahan, adanya pembinaan setiap hari adanya kerjasama dengan BK untuk menangani permasalahan murid, adanya kerjasama dengan orang tua serta selalu hadir dalam setiap kegiatan siswanya.

Pelaksanaan bimbingan dan konseling dalam pendidikan karakter peserta didik di Madrasah Aliyah Negeri 1 Kota Bandung disesuaikan dengan peraturan Menteri Pendidikan Nomor 111 tahun 2014 tentang bimbingan dan konseling yang meliputi layanan dasar, layanan responsi, layanan peminatan dan perencanaan individual 
peserta didik, dan dukungan sistem. Dalam pelaksanaan program bimbingan dan konseling metode yang dilakukan sesuai program kegiatan yang telah dirumuskan sebelumnya seperti bimbingan klasikal, bimbingan kelompok, konseling individual ataupun konseling kelompok serta metode-metode lainnya yang mendukung kegitan bk seperti konferensi kasus, advokasi ataupun konsultasi. Selain itu dalam pelaksanaan bimbingan dan konseling diteliti juga berbagai aspek baik bidang layanan bimbingan konseling, jenis layanan bimbingan konseling, pemotivasian peserta didik dan juga kegiatan pembentuk karakter seperti ekstrakurikuler.

Dalam bidang layanan bimbingan dan konseling meliputi berbagai aspek baik secara pribadi, sosial, belajar dan karir secara aspek peribadi melihat masalah yang dihadapi peserta didik yaitu masalah yang disebabkan karena faktor dirinya sendiri.Apalagi menginjak sekolah menengah jumlah permasalahnnya meningkat karena mereka dalam fase remaja, dimana fase ini sangat rentan dalam berbagai masalah pribadi.Dalam masalah pribadi ini biasanya menyangkut dengan penyesuaian peserta didik dengan lingkungan madrasah, masalah dengan teman sebayanya, masalah dengan gurunya ataupun masalah-masalah yang berkaitan dengan peserta didik itu sendiri.

Adapun dalam aspek sosial masalah yang sering dihadapi adalah masalah yang berhubungan dengan lingkungan peserta didik, yang berupa masalah dengan teman sebaya, dan sebagainya. Peserta didik pada saat usia remaja pada umumnya lebih banyak melakukan aktivitas dengan teman sebayanya. Positif dan negatif pun bisa saja terjadi pada proses pergaulannya, sisi negatif inilah yang biasanya berpengaruh kepada sikap tidak baik kepada peserta didik. apabila tidak dapat mengubah sesuai norma atau peraturan kelompoknya, maka peserta didik tersebut akan menarik diri atau disingkirkan dari kelompok teman sebaya mereka. Masih banyaknya kubu atau kelompok-kelompok didalam kelas dan hal ini menjadi permasalahan sosial yang paling sering terjadi di lingkungan sekolah/madrasah. Sedangkan dalam masalah belajar peserta didik cenderung belum sadar, menurut peserta didik sendiri yang menjadi permasalahan peserta didik adalah banyaknya tugas yang diberikan oleh guru-guru, padahal dalam pemahaman belajar, kurangnya konsentrasi hal itu juga merupakan permasalahan dalam belajar

Layanan bimbingan dan konseling memiliki banyak jenis diantaranya layanan orientasi, informasi, penempatan, konseling individual, konseling kelompok dan yang lainnya.jenis layanan bimbingan dan konseling yang diutamakan di Madrasah Aliyah Negeri 1 Kota Bandung adalah layanan informasi karena pada layanan ini dibukakan informasi sebanyak banyaknya dan peserta didik dapat mengetahui berbagi hal. sedangkan dalam pemotivasian yang dilakukan adalah menjadi rutinitas sehari-hari baik dalam aspek pribadi, sosial, belajar dan yang lainnya..

Adapun pada pelaksanaan kegiatan pendidikan karakter di Madrasah Aliyah Negeri 1 Kota Bandung difokuskan kepada dua macam model yaitu habituasi dan intervensi dalam model habituasi yaitu dilakukan pembiasaan kepada peserta didik seperti sholat berjamaah, sholat Duha, salam dan kepada siapapun yang dituangkan 
kedalam program kegiatan baik yang bersifat harian, ataupun mingguan. hal ini dimaksudkan agar peeserta didik memiliki karakter yang religius, empati, betanggung jawab, istiqomah, disiplin dan juga taqwa. Sedangkan model intervensi yaitu model yang berfokus pada kedisiplinan peserta didik baik dalam segi waktu, tempat dan komunikasi hal ini bertujuan agar peserta didik memiliki karakter yang religius. Adapun kegiatan pembentuk karakter peserta didik yaitu dengan adanya kegiatan ekstrakurikuler seperti Pramuka, Garis (gabungan remaja islam), teater, karawitan, olahraga seperti futsal, voli, dan juga bidang-bidang lainnya, sehingga peserta didik dapat menuangkan minat dan bakatnya melalui ekstrakurikuler.

Evaluasi layanan bimbingan dan konseling dilaksanakan dalam bentuk laporan baik kuantitatif dan kualitaif pada evaluasi kuantitatif ini berisikan data-data informasi mengenai peserta didik baik dalam layanan bimbingan dan konseling baik dalam layanan individu, kelompok ataupun klasikal. Dalam layanan individu dalam seminggu bisa mencapai lima sampai sepuluh peserta didik tentunya dalam hal ini berkaitan dengan konsultasi terhadap karir atau pendidikan lanjutan ataupun dengan masalah-masalah yang sedang dihadapi siswa, selain itu dalam layanan kelompok dalam sehari bisa mencapai dua atau tiga kelompok melihat dari kesamaan masalah yang dihadapi oleh peserta didik, untuk layanan klasikal dalam sehari biasanya mencapai tiga kelas. Adapun evaluasi hasil yang dirasakan belum maksimal karena pemahaman bimbingan peserta didik tentang layanan bimbingan dan konseling masih belum memuaskan hal ini ditandai dengan pemahaman sisiwa dalam memecahkan masalah-masalah yang sering dihadapi oleh dirinya, kemudian juga ditanndai dengan bagaimana siswa mampu mengambil keputusan untuk jenjang karir dan juga menentukan langkah-langkah kedepan.

Dalam faktor penunjang manajemen bimbingan dan konseling di Madrasah Aliyah Negeri 1 Kota Bandung pada intinya terdapat pada pemahaman seluruh civitas akademik baik dari kepala sekolah, guru-guru terhadap layanan bimbingan dan konseling cukup baik, sehingga memudahkan dalam pelaksanaan bimbingan dan konseling dapat berjalan secara efektif dan efesien. Selain itu keikutsertaan peserta didik dalam bekerjasama dengan guru bimbingan konseling menjadi pelaksanaannya lebih efektif. Adapun ketersediaan fasilitas yang cukup lengkap baik dari segi sarana dan prasarana bimbingan dan konseling seperti alat-alat cek masalah peserta didik, media seperti proyektor, serta ruang bimbingan konseling yang nyaman dan luas merupakan faktor penunjang dalam layanan Bimbingan Konseling.I

Adapun faktor penghambat dalam layanan Bimbngan Konseling yaitu kurangnya sumber daya manusia sehingga hal ini menjadi kurang maksimal dalam pelaksanaan bimbingan dan konseling. Adapun faktor penghambat lainnya yaitu kurang terbukanya sebagian peserta didik tentang permasalahan yang sedang dihadapi.Selain itu alokasi waktu yang sedikit menjadi faktor penghambat pelaksanaan bimbingan dan konseling, karena itu dalam pelaksanaan bimbingan konseling harus menggunakan sela-sela waktu kosong seperti jam istirahat. 
Keberhasilan yang dicapai di Madrasah Aliyah Negeri 1 Kota Bandung dalam layanan bimbingan dan konseling diukur dari pemahaman peserta didik terhadap layanan yang diberikan terutama dalam pemecahan masalah, dan pengambilan keputusan keberhasilan tersebut meliputi perubahan segi prilaku sikap/moral peserta didik, prestasi belajar, kedisiplinan dan lainnya sebagainya keberhasilan yang menjadi dominasi dan dirasakan oleh peserta didik adalah motivasi mengenai pendidikan lanjutan/ universitas dan dari tahun ke tahun dirasakan peningkatan jumlah peserta didik yang diterima diberbagai perguruan tinggi.

\section{Simpulan}

Perencanaan bimbingan dan konseling dalam pendidikan karakter peserta didik di Madrasah Aliyah Negeri 1 Kota Bandung dilakukan dengan analisis kebutuhan peserta didik, penentuan tujuan, penentuan jenis, teknis dan strategi kegiatan BK serta penentuan waktu, tempat dan fasilitas dalam kegiatan layanan Bimbingan dan Konseling.

Pengorganisasian bimbingan dan Konseling Madrasah Aliyah Negeri 1 Kota Bandung dalam pendidikan karakter peserta didik ini bukan hanya menjadi tanggung jawab bersama semua guru bimbingan dan konseling melainkan menjadi tanggung jawab semua guru. Adanya sistem koordinasi atau kerja sama baik antara guru bimbingan dan konseling dengan wali kelas atau guru mata pelajaran menjadikan pelaksanaan kegiatan bimbingan dan konseling lebih efektif.

Pelaksanaan bimbingan dan konseling di Madrasah Aliyah Negeri 1 Kota Bandung dilaksanakan sesuai dengan Peraturan Menteri Pendidikan Nomor 111 tahun 2014 yang meliputi layanan dasar, layanan responsi, layanan peminatan dan perencanaan individual peserta didik, dan dukungan sistem. Selain itu pelaksanaan bidang layanan bimbingan dan konseling dilaksanakan sesuai rumusan kebutuhan mencakup aspek pribadi, sosial, belajar, karir peserta didik.Guru BK harus pandai mendekati peserta didik baik dalam secara pendekatan emosional setiap dan setiap guru memiliki cara masing-masing dalam mendidik peserta didiknya pelayanan utama bimbingan dan konseling di Madrasah Aliyah Negeri 1 Kota Bandung yang diberikan berupa pelayanan informasi, hal ini dikarenakan dalam pelayanan informasi dibuka mengenai informasi-informasi penting yang berkaitan dengan peserta didik seperti informasi pendidikan lanjutan (karir). Dalam pembentukan karakter peserta didik bisa di lakukan melalui pemberian motivasi dari BK serta kegiatan-kegiatan yang menujang dalam pendidikan karakter seperti ekstrakurikuler.

Evaluasi manajemen bimbingan dan konseling yang dilaksanakan di Madrasah Aliyah Negeri 1 Kota Bandung dilakukan dengan bentuk laporan baik yang bersifat kualitatif maupun yang bersifat kuatitatif. Secara kuantitaif dapat diketahui jumlah peserta didik yang terlayani baik dalam klasikal sebanyak tiga kelas perharinya, individual lima sampai sepuluh peserta didik dalam seminggu dan juga kelompok satu atau dua kelompok perharinya. Secara kualitatif berhubungan dengan permasalahan sosial, pribadi, belajar maupun peserta didik. 
Dengan adanya faktor pendukung dalam pelaksanaan bimbingan dan konseling di sekolah. Maka akan mudah guru BK dalam menangani setiap permasalahan yang dihadapi klien /peserta didik. walaupun masih banyak faktor penghambat terutama kurangnya personil tetapi dengan kerja sama antar guru maka pelaksanaan bimbingan dan konseling dapat berjalan secara efektif.

Hasil yang dicapai dari adanya bimbingan dan konseling diantaranya perubahan perilaku siswa menjadi lebih baik, dan meningkatnya prestasi yang diraih, serta meningkatnya kedisiplinan siswa.

\section{Daftar Pustaka}

Adisusilo, S. (2012). Pembelajaran Nilai- karakter Kontruktivisme dan VCT sebagai Inovasi Pendekatan Pembelajaran Afektif. Jakarta: Raja Grapindo Persada.

Akhirudin.(2015). Lembaga Pendidikan Islam di Nusantara.Jurnal Tarbiya, 1 (1):Universitas Islam Negeri Sunan Gunung Djati Bandung.

Athoilah.A (2010).Dasar-dasar Manajemen. Jakarta: INDEKS

Badrudin. (2013). Manajemen Peserta didik. Jakarta: INDEKS.

Badrudin. (2015). Dasar-dasar Manajemen. Bandung: Alfabeta.

Creswell, W. J. (2013). Reseach Design: Pendekatan Kualitatif, Kuantitatif, dan Mixed, edisi ketga. Yogyakarta: Pustaka Pelajar.

Dumhur, \& Surya, M. (2015). Peningkatan kemampuan penyesuaian diri menggunakan teknik reinforcement positif. Jurnal Bimbingan dan Konseling.

Fathurrahman, P. (2002). Bimbingan dan Konseling dalam Pendidikan. Bandung: Pustaka Adhigama.

Gunawan, H. (2012). Pendidikan Karakter Konsep dan Implementasi. Bandung: ALFABETA.

guruKatro. (2016, Februari 1). https://www.guruKatro.com/2016/01/standarkompetensi-lulusan-pendidikan.html?m=1. Retrieved Mei 4, 2019, from www.guruKatro.com

Hasibuan, M. S. (2006). Manajemen (Dasar, Konsep, dan Masalah). Jakarta: Bumi Aksara.

Hikmawati, F. (2012). Bimbingan dan Konseling. Jakarta: Rajawali Pers.

Iqbal. (2005, oktober 6). https://wikipedia.org/wiki/Madrasah_aliyah. Retrieved April 6, 2019, from www.wikipedia.com: https://wikipedia.org/wiki/Madrasah_aliyah

Isnaini, R. L. (2016). Penguatan Pendidikan Karakter siswa melalui manajemen bimbingan dan konseling Islam. Jurnal Manajemen Pendidikan Islam, 36.

Jahari, J., \& Syarbini, A. (2013). Manajemen Madrasah. Bandung: Alfabeta.

K.A Rahman, M. M. (2017). Manajemen Bimbingan dan Konseling di SMA Negeri. Jurnal Administrasi Pendidikan, 41.

Koesoema, A. D. (2011). Pendidikan Karakter Strategi Mendidik Anak di Zaman global. Jakarta: PT. Gramedia.

Lisyarti, R. (2012). Pendidikan Karakter dalam metode aktif, inovatif, dan kreatif. Jakarta: Erlangga Group. 
Moleong, L. J. (2011). Metodologi Penelitian Kualitatif. Bandung: PT Remaja Rosda Karya.

Nurihsan, A. J. (2006). Bimbingan dan Konseling dalam berbagai latar kehidupan. Bandung: Alfabeta.

Nurihsan, A. J. (2006). Bimbingan dan Konseling dalam berbagai latar kehidupan. Bandung: PT Refika Aditama.

Salahudin, A. (2010). Bimbingan dan Konseling. Bandung : Pustaka Setia.

Saptono. (2011). Dimensi-dimensi Pendidikan Karakter Wawasan, Strategi dan Langkah Praktis. Jakarta: Esensi.

Sukardi, D. K. (2000). Pengantar dan Pelaksanaan Bimbingan dan Konseling di Sekolah. Jakarta: Rineka Cipta.

Syah, M. (2017). Psikologi pendidikan dengan pendekatan baru. Bsndung: PT Rosda Karya.

Tohirin. (2014). Bimbingan dan Konseling di Sekolah dan Madrasah. Jakarta: Rajawali Pers.

Walgito, B. (2010). Bimbingan dan Konseling (Studi dan Karier). Yogyakarta: ANDI.

Yusuf, S. (2005). Pengembangan Program Bimbingan dan Konseling. ABKIN. 